\title{
Larval development of Lepidophthalmus siriboia Felder \& Rodrigues, 1993 (Decapoda: Thalassinidea) from the Amazon region, reared in the laboratory.
}

\author{
Fernando A. ABRUNHOSA ${ }^{1}$; Marcus Alexandre B. PIRES ${ }^{1}$; Jô de Faria LIMA ${ }^{1}$; Petrônio Alves COELHO-FILHO ${ }^{2}$
}

\begin{abstract}
The complete larval development of the ghost shrimp Lepidophthalmus siriboia Felder \& Rodrigues, 1993 was described and illustrated in detail from specimens reared in the laboratory. Ovigerous females were collected at Canela Island in the northeastern region of the State of Pará. The larvae hatch as a prezoea, in which they persist for less than 3 hours. The larval development consists of three zoeal stages and a megalopa. The zoeal development averaged from 69 to 111 hours. The period in the megalopa stage was about 185 hours (about 8 days). The percentage of individuals succeeding in molt into juvenile stage was $91,8 \%$. The first juvenile stage was reached 254 hours (about 10 days) after hatching. Morphological comparisons and their relationship with larvae of congeneric species are briefly discussed.
\end{abstract}

\section{KEY WORDS}

Larval development, Thalassinidea, Callianassidae, Lepidophthalmus siriboia.

\section{O desenvolvimento larval de Lepidophthalmus siriboia Felder \& Rodrigues, 1993 (Decapoda: Thalassinidea) da região amazônica, cultivado em laboratório.}

\begin{abstract}
RESUMO são discutidas.

PALAVRAS-CHAVE

Desenvolvimento larval, Thalassinidea, Callianassidae, Lepidophthalmus siriboia.
\end{abstract}

O desenvolvimento completo de Lepidophthalmus siriboia Felder $\varepsilon$ Rodrigues, 1993 foi descrito e ilustrado em detalhes a partir de espécimens cultivados em laboratório. Fêmeas ovígeras foram coletadas na ilha de Canela nordeste do Estado do Pará. As larvas eclodem como prezoea e o desenvolvimento larval consiste de 3 estágios de zoea e 1 de megalopa. O desenvolvimento dos 3 estágios de zoea durou em média de 69 a 111 horas. A duração de megalopa foi cerca de 185 horas (cerca de 8 dias). O primeiro juvenil foi alcançado em 254 horas (cerca de 10 dias) após a eclosão. Comparações morfológicas com espécies do mesmo gênero

\section{INTRODUCTION}

In Brazil, the family Callianassidae includes 9 genera (Biffarius, Callichirus, Cheramus, Corallianassa, Eucalliax, Lepidophthalmus, Neocallichirus, Poti and Sergio) with 19 species described. There is only one species of the genus Lepidophthalmus, L. siriboia Felder \& Rodrigues, 1993 (cf. Melo, 1999). This species occurs from Florida USA to the Brazilian coast in the states of Pará, Maranhão, Paraíba and Bahia (Rodrigues \& Shimizu, 1998; Melo, 1999).

L. siriboia has been confused in previous literature under the name Callianassa jamaicense (Rodrigues \& Shimizu,
1998). However, after an accurate comparative description with another congeneric species, L. louisianensis, L. siriboia was named as a new species (Felder \& Rodrigues, 1993; Rodrigues \& Shimizu, 1998).

An important study on larvae of this genus Lepidophthalmus was accomplished by Nates et al. (1997) in which the authors report a detailed description of two species, L. sinuensis, from the coast of Colombia, and $L$. louisianensis, from the Gulf of Mexico. In Brazil, few studies on the Callianassidae larvae are available. Two studies on larval descriptions were focused on two callianassids, Callichirus major and Sergio mirim

\footnotetext{
${ }^{1}$ Núcleo de Estudos Costeiros, Universidade Federal do Pará, Campus de Bragança, Alameda Leandro Ribeiro s/n, Aldeia, 68.600-000 Bragança, PA, Brasil. E-mail faraujo@ufpa.br

${ }^{2}$ Depto de Oceanografia, Universidade Federal de Pernambuco, Av. Arquitetura s/n, Cidade Universitária, 50.670-901 - Recife-PE. E-mail: pacf@ufpe.br
} 


\section{ACTA AMAZONICA}

LARVAL DEVELOPMENT OF LEPIDOPHTHALMUS SIRIBOIA FELDER \& RODRIGUES, 1993 (DECAPODA: THALASSINIDEA) FROM THE AMAZON REGION, REARED IN THE LABORATORY.
(=Callichirus mirim) described by Rodrigues $(1976,1984)$, respectively. However, there are no references for studies on the Lepidophthalmus larvae.

In the present paper, the morphological descriptions and illustrations of the larval, megalopa and first juvenile stages of L. siriboia are provided and comparisons are made with other congeneric species.

\section{MATERIAL AND METHODS}

Ovigerous females of Lepidophthalmus siriboia were collected from burrows with a handmade sucking tube (height $=1 \mathrm{~m}$ and diameter $=8 \mathrm{~cm})$ on Canela island, Pará $\left(00^{\circ} 47^{\prime} 06^{\prime \prime} \mathrm{S}\right.$, $\left.46^{\circ} 43^{\prime} 41^{\prime \prime} \mathrm{W}\right)$. The females were transported to the laboratory individually, immersed in marine water (salinity $36 \%$ and $\mathrm{pH}$ 8.1) and kept in small plastic containers (capacity $300 \mathrm{~mL}$ ) with substrate from the collection place. In the laboratory, the females were placed in $10 \mathrm{~L}$ aquariums filled with seawater until hatching.

The larvae were placed in 11 plastic recipients (capacity 300 $\mathrm{mL}$ ) with 10 larvae/recipient. The larvae were fed with Artemia nauplii and each day they were transferred into newly prepared containers. Exuviae and some individuals were preserved in glycerol + ethylic alcohol $70 \%$ solution after each molting. At least 10 individuals from each stage were dissected and illustrated.

The carapace length (CL) was measured dorsally from the orbital region to the posterior midpoint. The illustrations and measurements of the larvae and postlarvae were made under a Zeiss binocular microscope equipped with a micrometer disc. The nomenclature used follows Nates et al. (1977), Strasser \& Felder (1999) and Melo \& Brossi-Garcia (2000). The term megalopa was used for the transitional stage instead of glaucothoe.

\section{RESULTS}

\section{Larval culture}

The larvae hatched after being incubated 7 days. Hatched larvae were obtained from 3 females. The larvae hatch as prezoea in which they did not have natatorium movement (Fig. 2). The prezoea period was about 3 hours. The larval development consists of 3 zoeal stages and one megalopa stage. No feeding activity was observed in the zoeal larvae. The Zoea I period lasted an average of 14 hours, in which about $50 \%$ of the larvae succeeded in molting to the next stage. Only one individual was found dead in this stage. In fact, low mortality was observed during the whole zoeal and megalopa stages (Fig. 1).

The first megalopae were obtained 69 hours after hatching (approx. 3 days) (Fig. 1, 2). Contrary to zoea larvae, the megalopa had been very active in the capture of Artemia, but no cannibalism was observed among the megalopae. The megalopa period extended 254 hours after hatching, at which time they started molting into Juvenile I. Cannibalism was frequently observed among Juvenile I.

\section{Description of Larval and Juvenile I Stages}

The first stage of $L$. siriboia is described in detail. Only main morphological changes will be described for the stages following the Zoea I.

\section{ZOEA I (Fig. 3a)}

Period (Fig. 1) - 3 to 19 hours

Carapace length: $1.15 \mathrm{~mm}(1.02-1.24 \mathrm{~mm})$.

Carapace (Fig. 3a) -Shorter than abdomen; rostrum distinct curved downward; eyes subcylindrical not fused with carapace.

Abdomen (Fig. 3a)-Somites 2-5 with posterodorsal spines;
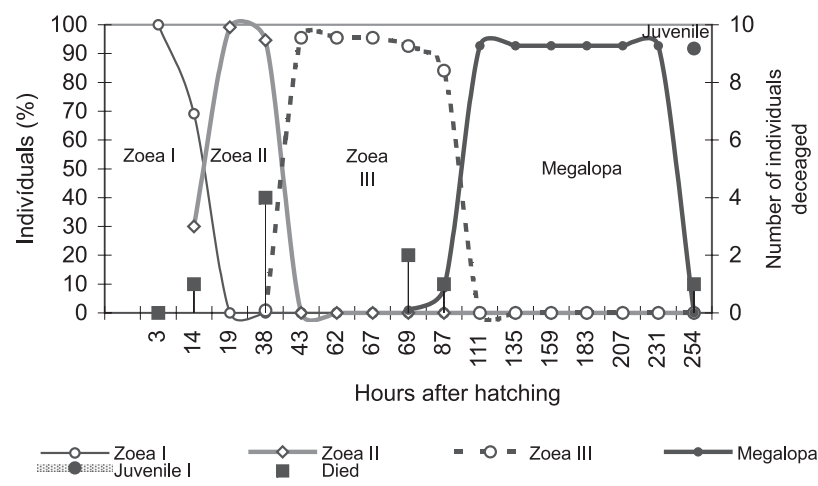

Figure 1 - Percentage of survival and rearing period of Lepidophthalmus siriboia from Zoea I to Juvenile I reared in the laboratory.

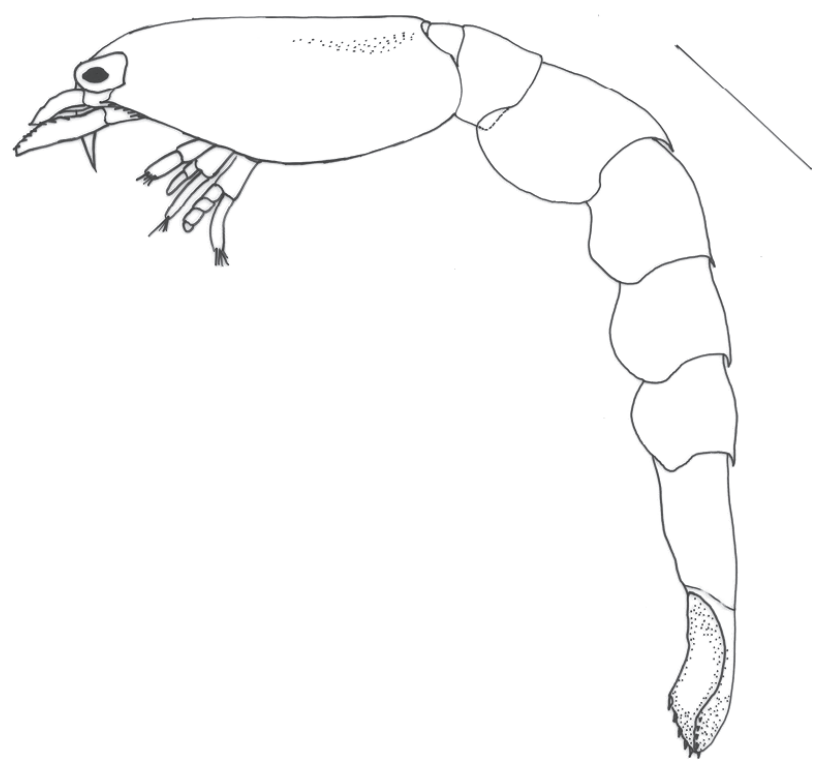

Figure 2 - Lepidophtalmus siriboia Felder \& Rodrigues, 1993. Lateral view of a prezoea. Scale bar: $0.7 \mathrm{~mm}$. 


\section{ACTA \\ AMAZONICA}

LARVAL DEVELOPMENT OF LEPIDOPHTHALMUS SIRIBOIA FELDER \& RODRIGUES, 1993 (DECAPODA: THALASSINIDEA) FROM THE AMAZON REGION, REARED IN THE LABORATORY. dorsal spine elongate on somite 2; segmentation between somite 6 and telson not distinctly visible.

Antennule (Fig. 4a) - Elongate; unsegmented with $1+4$ aesthetascs (1 longer) and 2 simple setae; small, distinct endopodal lobe bearing 1 plumose seta.

Antenna (Fig. 4b) - Biramous; protopod with 1 strong spine; endopod unsegmented with 3 plumose setae; scaphocerite armed with 1 strong distolateral spine and 11-12 plumose setae.

Maxillule (Fig. 4c)-Coxal and basal endites lackingsetae, bearing small marginal spines; endopod unsegmented, lacking setae.

Maxilla (Fig. 4d) - Basal and coxal endites bilobed, lacking setae; endopod unsegmented, lacking setae; scaphognathite with 3-4 setae marginal on anterior and 2 setae on posterior margins.

First maxilliped (Fig. 4e) - Basipod lacking setae or showing a row of minute marginal setae; endopod incompletely 2segmented with 2-3 distal setae; exopod with 4 plumose setae.

Second maxilliped (Fig. 4f) - Basipod lacking setae; endopod 4-segmented with $1+1$ setae on the distal segment; exopod with 4 plumose setae.

Third maxilliped (Fig. 4g)-Basipod lacking setae; endopod
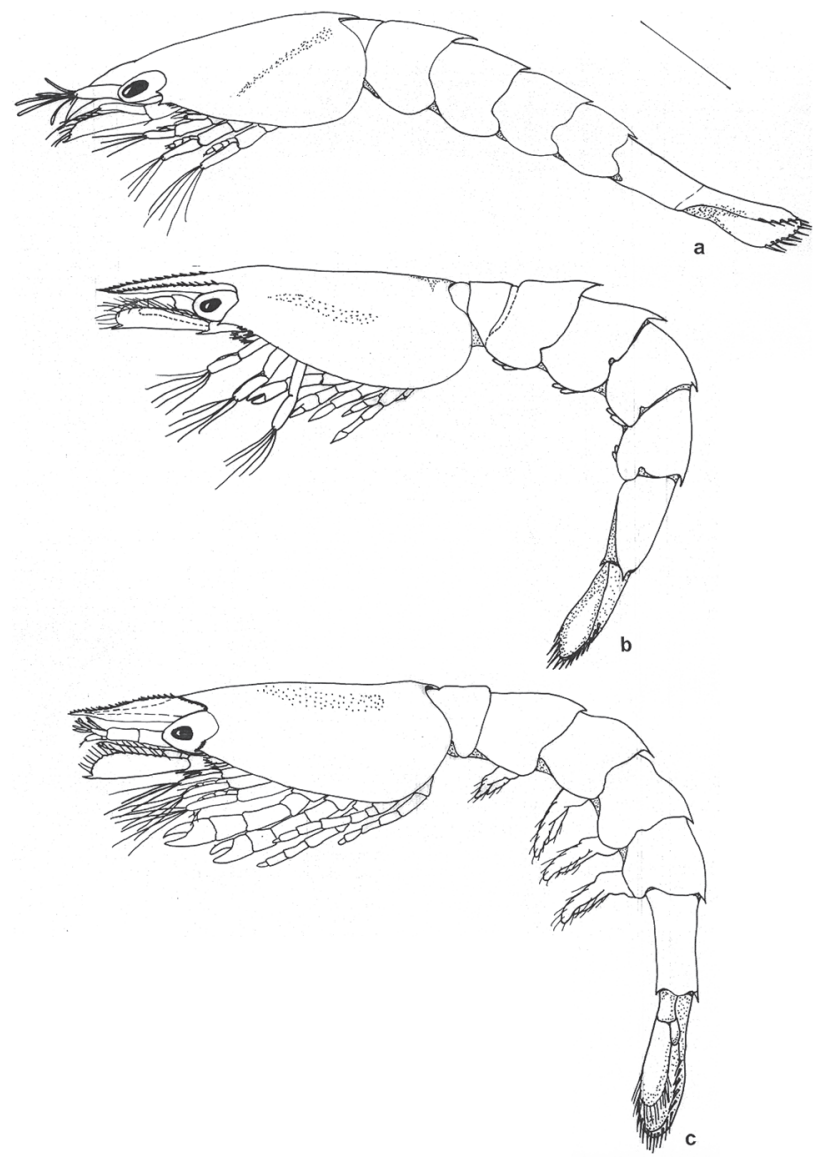

Figure 3 - Lepidophtalmus siriboia Felder \& Rodrigues, 1993. Lateral view of zoeae. a, stage I; b, stage II; c, stage III. Scale bar: $\mathrm{a}, \mathrm{b}$ and $\mathrm{c}=0.70 \mathrm{~mm}$. 4-segmented with $2+1$ setae on distal segment; exopod with 5 plumose setae.

Pleopods - Not developed

Pereiopods-Not developed.

Urupods - Not developed.

Telson (Fig. 4h) - Subtriangular; narrower anteriorly and incompletely articulated with 6th abdominal somite; posterior margin with $7+1+7$ setae.

\section{ZOEA II (Fig. 3b)}

Period (Fig. 1) - 8 to 43 hours.

Carapace length $-1.22 \mathrm{~mm}(1.20-1.26 \mathrm{~mm})$.

Carapace (Fig. 3b) - Rostrum straight, broad and bearing a row of small denticles on lateral margins.

Abdomen (Fig 3b) - Somites 3 to 4 with posterolateral spines, segmentation evident between $6^{\text {th }}$ abdominal somite and telson.

Antennule (Fig. 5a) - Biramous; peduncle 2-segmented, distal segment with $3+2$ plumose setae marginal; endopod with an elongate terminal seta; exopod with $2+(6-8)$ aesthetascs and 2 simple setae.

Antenna (Fig. 5b) - Biramous; protopod with 2 strong

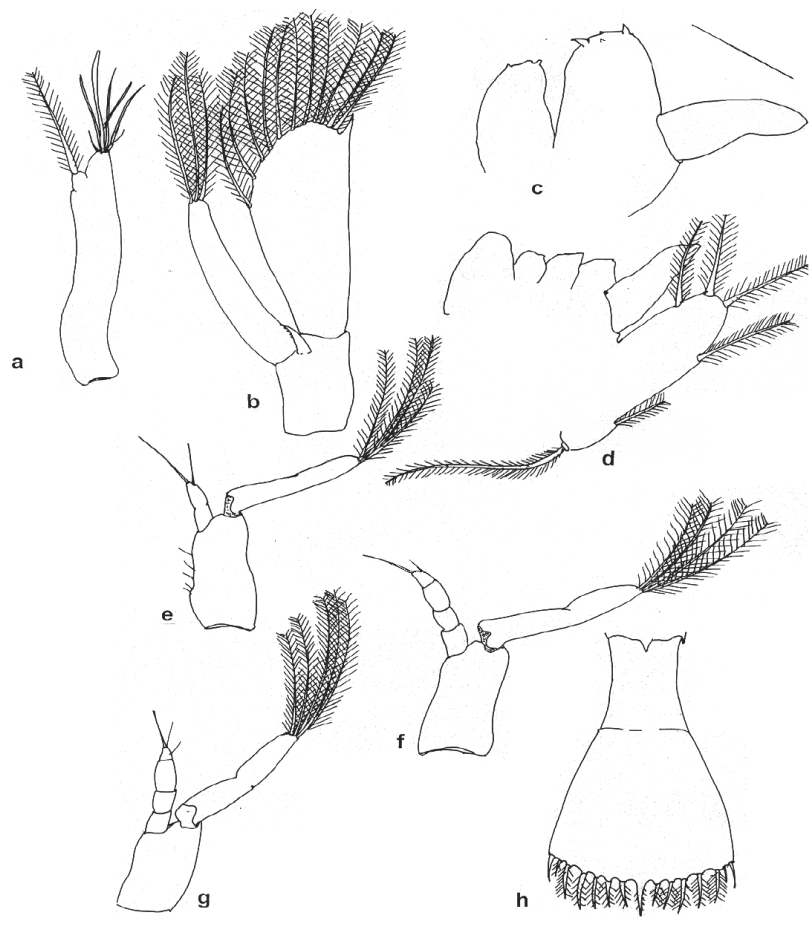

Figure 4 - Lepidophtalmus siriboia Felder \& Rodrigues, 1993. Zoea I appendages. a, Antennule; b, Antenna; c, Maxillule; d, Maxilla; e, First maxilliped; f, Second maxilliped; g, Third maxilliped; $\mathrm{h}$, Telson. Scale bar: $\mathrm{a}, \mathrm{b}, \mathrm{e}, \mathrm{f}$ and $\mathrm{g}=0.3 \mathrm{~mm}$; $\mathrm{c}=$ $0.07 \mathrm{~mm} ; \mathrm{d}=0.1 \mathrm{~mm} ; \mathrm{h}=0.6 \mathrm{~mm}$. 
spines; endopod with 3 simple setae terminally (sometimes absent); scaphocerite with a strong distolateral spine, 15 elongate and 1 simple setae.

Maxillule (Fig. 5c) - Similar to previous stage.

Maxilla (Fig. 5d) - Scaphognathite with (10-13)+1 plumose setae.

First maxilliped (Fig. 5e) - Basipod with row of simple setae; endopod 3-segmented with 2 distal setae; exopod with 5 plumose setae.

Second maxilliped (Fig. 5f) - Endopod 5-segmented; exopod with 5 plumose setae.

Third maxilliped (Fig. 5g) - Similar to previous stage.

Pereiopods 1 and 2 (Fig. 5i) -Chelated; endopods 5-segmented; exopods rudimentary lacking setae or with a small simple setae.

Pereiopods 3 e 4 (Fig. 5i) - Endopods 5-segmented; exopod rudimentary.

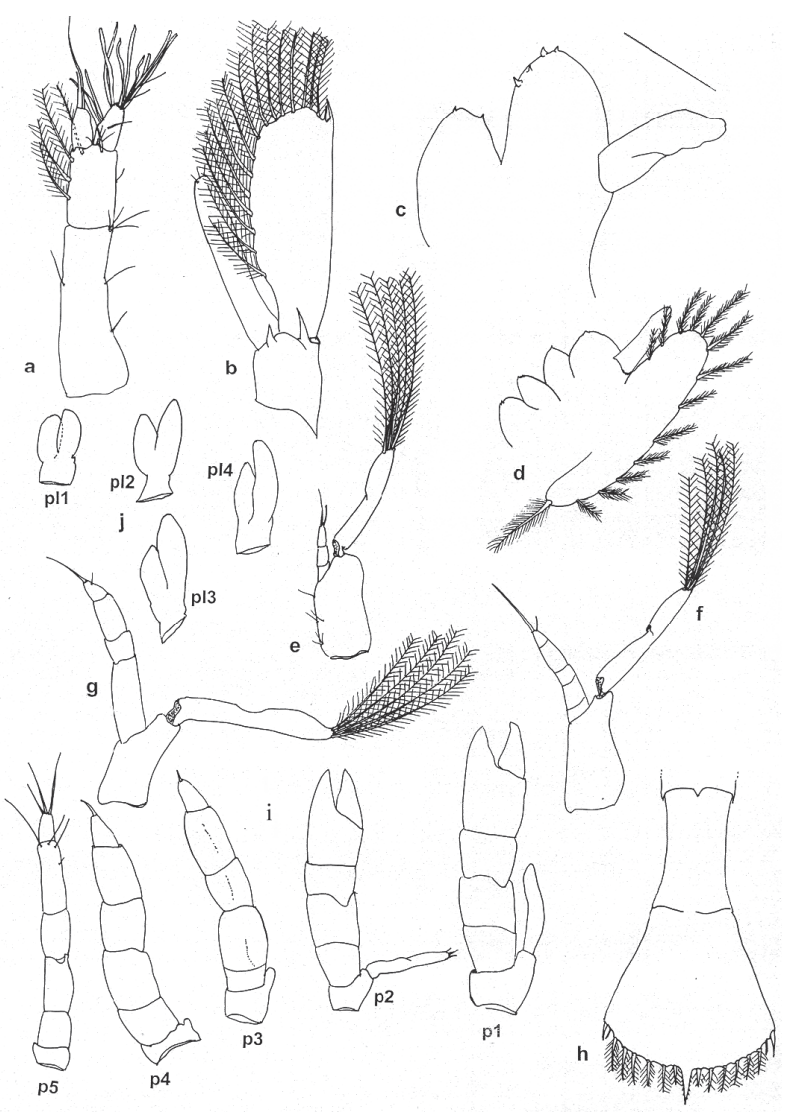

Figure 5 - Lepidophtalmus siriboia Felder \& Rodrigues, 1993. Zoea II appendages. a, Antennule; b, Antenna; c, Maxillule; d, Maxilla; e, First maxilliped; f, Second maxilliped; g, Third maxilliped; h, Telson; i, Pereiopods (p1 - p5); j, Pleopods (pl 1 - pl 4). Scale bar: a, b, e, f, g and $\mathrm{I}=0.3 \mathrm{~mm} ; \mathrm{c}=0.07 \mathrm{~mm} ; \mathrm{d}$ and $\mathrm{i}=0.1 \mathrm{~mm} ; \mathrm{h}=0.6 \mathrm{~mm}$.
Pereiopod 5 (Fig. 5i) - Uniramous; endopod 5-segmented with 3 setae on distal segment and $3+1$ setae on subdistal segment.

Pleopods 1 to 4 (Figs. 5j) - Bud, lacking setae.

Telson (Fig. 5h) - Similar to previous stage.

\section{ZOEA III (Fig. 3c)}

Period (Fig. 1) - 38 to 111 hours or 1.6 to 4.6 days

Carapace length $-1.19 \mathrm{~mm}(1.14-1.26 \mathrm{~mm})$.

Carapace (Fig. 3c) - Similar to previous stage.

Abdomen (Fig 3c) - Similar to previous stage.

Antennule (Fig. 6a) - Similar to previous stage

Antenna (Fig. 6b) -Endopod 4-segmented bearing 1 simple terminal seta; scaphocerite with a strong distolateral spine, 16 elongate and 1 simple setae.

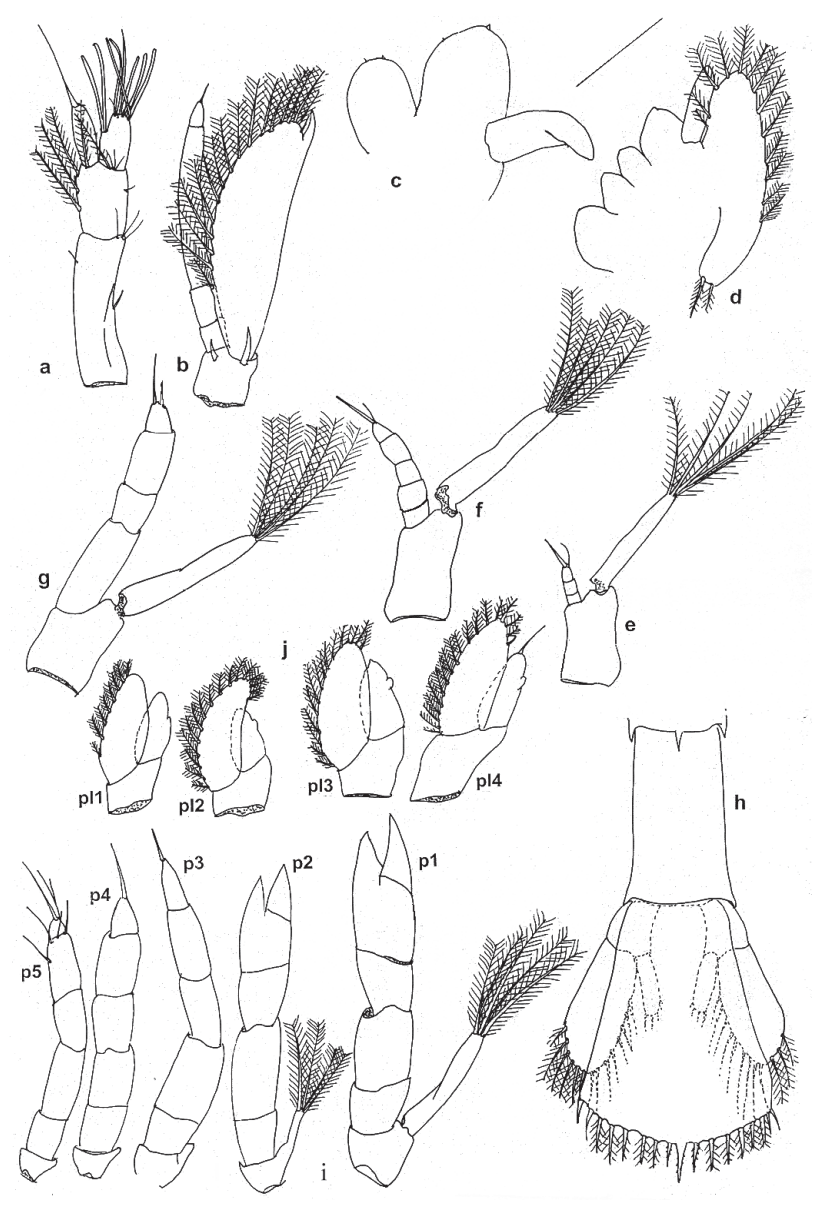

Figure 6 - Lepidophtalmus siriboia Felder \& Rodrigues, 1993. Zoea III appendages. a, Antennule; b, Antenna; c, Maxillule; d, Maxilla; e, First maxilliped; f, Second maxilliped; g, Third maxilliped; h, Telson; i, Pereiopods (p1 - p5); j, Pleopods (pl 1 - pl 4). Scale bar: a, b, e, f, g, j and i $=0.3 \mathrm{~mm} ; \mathrm{c}=0.07 \mathrm{~mm}$; $=0.1 \mathrm{~mm} ; \mathrm{h}=0.6 \mathrm{~mm}$. 


\section{ACTA \\ AMAZONICA}

LARVAL DEVELOPMENT OF LEPIDOPHTHALMUS SIRIBOIA FELDER \& RODRIGUES, 1993 (DECAPODA: THALASSINIDEA) FROM THE AMAZON REGION, REARED IN THE LABORATORY.
Maxillule (Fig. 6c) - Similar to previous stage.

Maxilla (Fig. 6d) - Scaphognathite with (12-13) +2 plumose setae.

First maxilliped (Fig. 6e) - Similar to previous stage.

Second maxilliped (Fig. 6f) - Similar to previous stage.

Third maxilliped (Fig. 6g) - Similar to previous stage.

Pereiopod 1 (Fig. 6i) - Exopod with 4 plumose setae.

Pereiopod 2 (Fig. 6i) - Exopod developed with 4 plumose setae.

Pereiopods 3, 4 and 5 (Fig. 6i) - Similar to previous stage.

Pleopods 1 to 4 (Figs. 6j) - More developed compared to previous stage; exopods with plumose marginal setae; endopods shorter than exopods, lacking setae in the most of individuals.

Telson (Fig. 6h) - Telson subrectangular.

Uropod (Fig. 6h) -Articulated with the last abdominal somite; exopod with 14 plumose setae; endopod rudimentary bearing (or not) marginal setae.
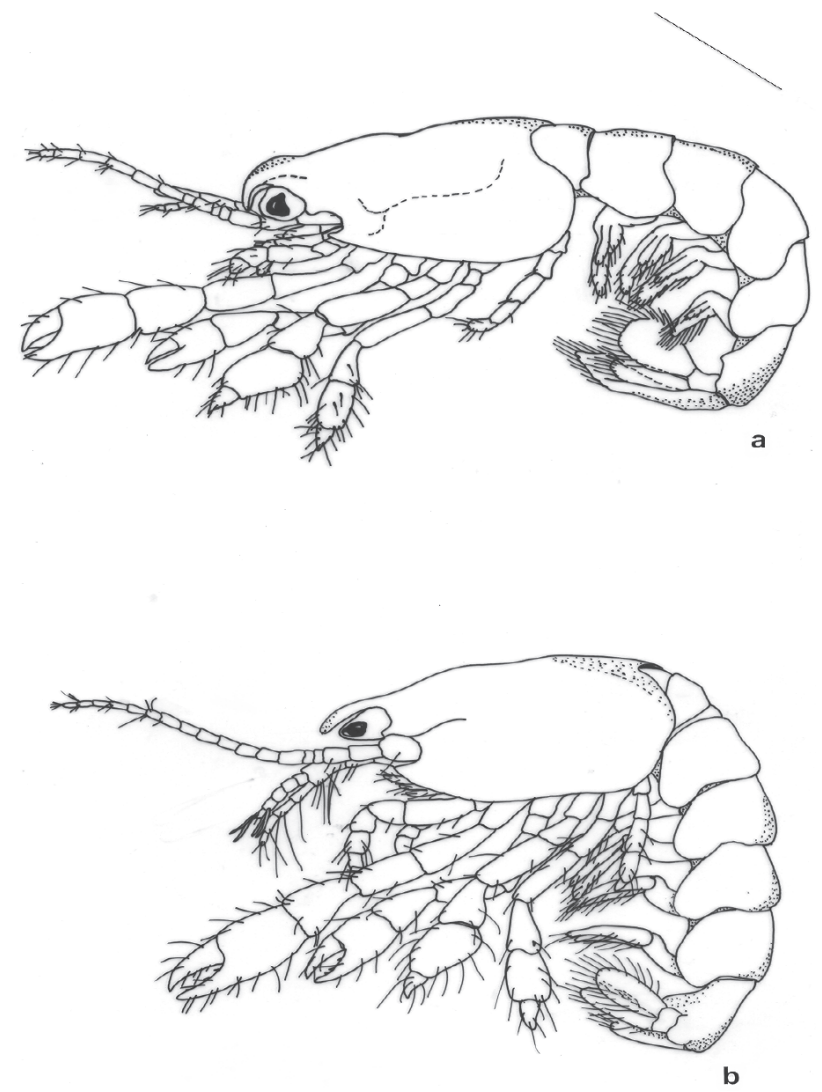

Figure 7 - Lepidophtalmus siriboia Felder \& Rodrigues 1993. Lateral view of Megalopa and Juvenile 1 stages: $a$, Megalopa; $b$, Juvenile. Scale bar: $a$ and $b=0.70 \mathrm{~mm}$.

\section{MEGALOPA (Fig. 7a)}

Period (Fig.1) -69 to 254 hours or 2.8 to 10.6 days.

Carapace length - $1.18 \mathrm{~mm}(1.14-1.24 \mathrm{~mm})$.

Carapace (Fig. 7a) - Shorter than the abdomen; rostral spine unarmed and curved downward; eyes subcylindrical.

Abdomen (Fig. 7a) - Somites 1-6 evident showing (or not) small spines posterodorsally.

Antennule (Fig. 8a) - Biramous; peduncle 3-segmented, proximal segment bearing a well developed statocyst with numerous setae, medial segment with 4 simple setae, distal segment with 7 elongate and 5 simple setae; endopod 4 segmented with 0,1,4,3 setae, respectively; exopod 3segmented, bearing 3 terminal and 2 subterminal aesthetascs.

Antenna (Fig. 8b) - Uniramous; flagellum with 14 segments, distal segment with 5 simple setae and 1 spine; exopod atrophied.

Maxillule (Fig. 8c) -Coxal endite with 9-14 marginal setae; basal endite with 11 marginal spines and 6 setae; endopod lacking setae.

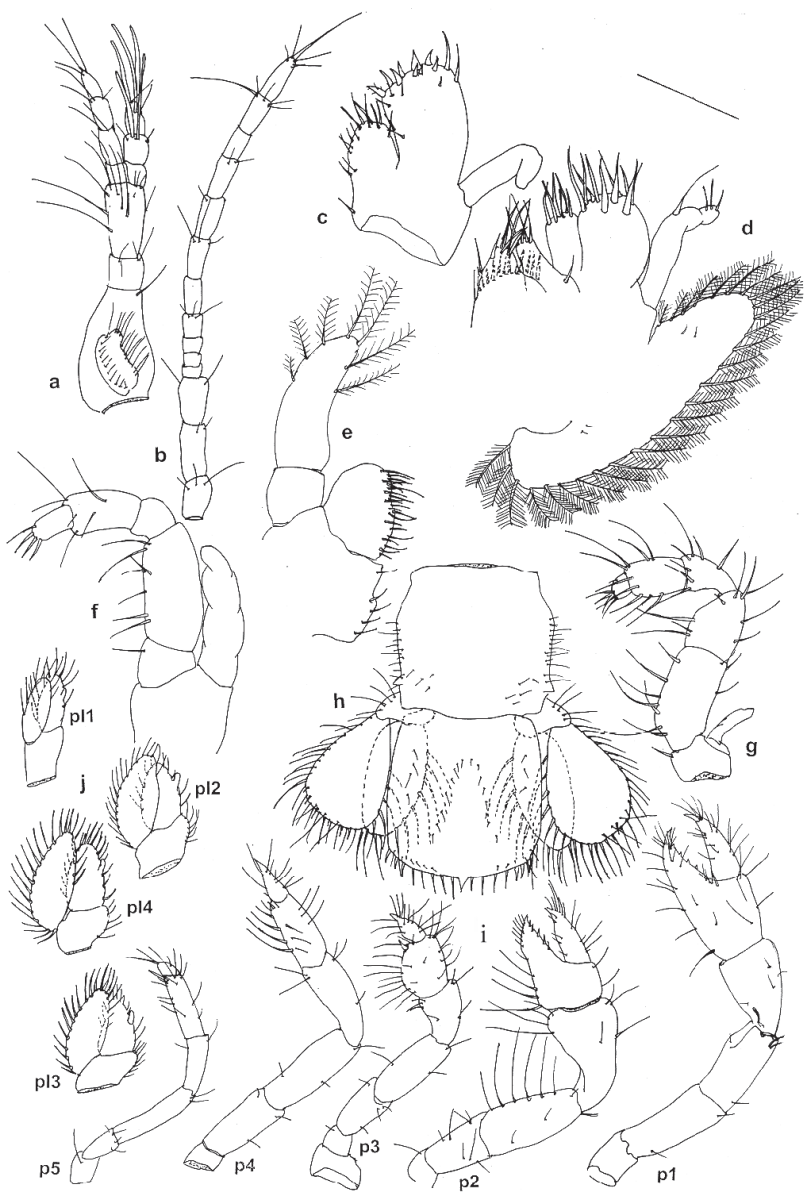

Figure 8 - Lepidophtalmus siriboia Felder \& Rodrigues, 1993. Megalopa appendages. a, Antennule; b, Antenna; c, Maxillule; d, Maxilla; e, First maxilliped; f, Second maxilliped; g, Third maxilliped; h, Telson; i, Pereiopods (p1 - p5); j, Pleopods (pl $1-\mathrm{pl}$ 4). Scale bar: $a, b, g, h, j$ and $i=0.3 \mathrm{~mm} ; \mathrm{c}=0.07 \mathrm{~mm} ; \mathrm{c}, \mathrm{d}, \mathrm{e}, \mathrm{f}=0.1 \mathrm{~mm}$. 


\section{ACTA \\ AMAZONICA}

LARVAL DEVELOPMENT OF LEPIDOPHTHALMUS SIRIBOIA FELDER \& RODRIGUES, 1993 (DECAPODA: THALASSINIDEA) FROM THE AMAZON REGION, REARED IN THE LABORATORY.
Maxilla (Fig. 8d) - Coxal endite trilobed, distal lobe with $12+7$ setae; proximal lobe with 5 setae; distal and proximal lobes of basal endite bearing 10 and 6 setae, respectively; endopod with $1+3$ simple setae; scaphognathite well developed with 27 plumose marginal setae.

First maxilliped (Fig. 8e) - Coxa and basal endites fused, showing 5 simple setae; endopod unsegmented with approximately 22 simple setae; exopod 2-segmented with 7 plumose setae on distal segment.

Second maxilliped (Fig. 8f) - Basipod with 1 simple seta; exopod without segmentation and devoid of setae; endopod 5-segmented with 1,7,0,6,4 setae, respectively.

Third maxilliped (Fig. 8g) - Basipod with 1 seta; exopod atrophied, lacking setae; endopod 5-segmented, with 10,9,7,9,5 setae, respectively.

Pereiopods 1 and 2 (Fig. 8i) - Chelated; uniramous; endopod 6-segmented, propodus and dactylus with numerous setae; exopod atrophied. Pereiopod 1 with ischium, merus and carpus bearing few seta; fixed finger with 4 spines in the inner margin. Pereiopod 2 shorter than pereiopod 1; ischium, merus and carpus bearing elongated setae; fixed finger with 5 spines in the inner margin.

Pereiopods 3 e 4 (Figs. 8i) - Uniramous; endopod 6segmented; propodus and dactylus with numerous setae; exopod atrophied. Pereiopod 4 longer than pereiopod 3. Pereiopod 3 more robust compared with pereiopod 4 and showing 1 small distal spine.

Pereiopod 5 (Fig. 8i) - Uniramous; endopod 6-segmented; propodus and dactylus with numerous setae; exopod atrophied.

Pleopod 1 (Fig. 8j) - Biramous; smaller than successive pleopods; basipod lacking setae. Endopod with 10 plumose setae; exopod with 9 plumose setae.

Pleopod 2-4 (Fig. 8j) - Biramous; basipod with 5-7 plumose setae; endopod with 10-16 plumose setae; exopod with 18-23 plumose setae.

Telson (Fig. 8h) - Telson subrectangular, with $10+10$ marginal process and 1 acute medial spine.

Uropod (Fig. 8h) - Uropod biramous; endopod, with 10 plumose setae; exopod larger than endopod with 30 plumose setae and 5 marginal spines.

\section{JUVENILE I (Fig. 7b)}

Period (Fig.1) - Over 231 hours or 9.6 days.

Carapace length-1.19 mm (1.16-1.24 mm).

Carapace (Fig. 7b) - Similar to megalopa stage.

Abdomen (Fig. 7b) - Similar to megalopa stage.

Antennule (Fig. 9a) - Biramous; peduncle 4-segmented, proximal segment showing a well developed statocyst, medial segment with 6 simple setae, distal segment with $7+4$ setae; endopod 5-segmented with $0,1,3,2,5$ setae, respectively; exopod 4-segmented, bearing 3 terminal and 2 subterminal aesthetascs.
Antenna (Fig. 9b) - Uniramous, flagellum with 18 segmentations, distal segment with 6 simple setae and 1 spine; exopod atrophied.

Maxillule (Fig. 9c) - Coxal endite with 19 marginal setae; basal endite with 11 marginal spines, 5+1 plumose setae subterminal; endopod with 1 simple seta subterminal; propodite with 1 simple seta.

Maxilla (Fig. 9d) - Coxal endite trilobed, with 20+10 setae; proximal lobe with 6 setae; basal endite bilobed, with 11 setae in distal lobe and 5 in the proximal lobe; endopod with $1+3$ simple setae; scaphognathite well developed with 28 marginal plumose setae.

First maxilliped (Fig. 9e) - Endopod unsegmented, with 28 simple setae; exopod unsegmented, bearing 15 distal plumose setae.

Second maxilliped (Fig. 9f) - Exopod 2-segmented, with 2 terminal setae; endopod 5-segmented, with 3,1,4,0,8,6 setae, respectively.

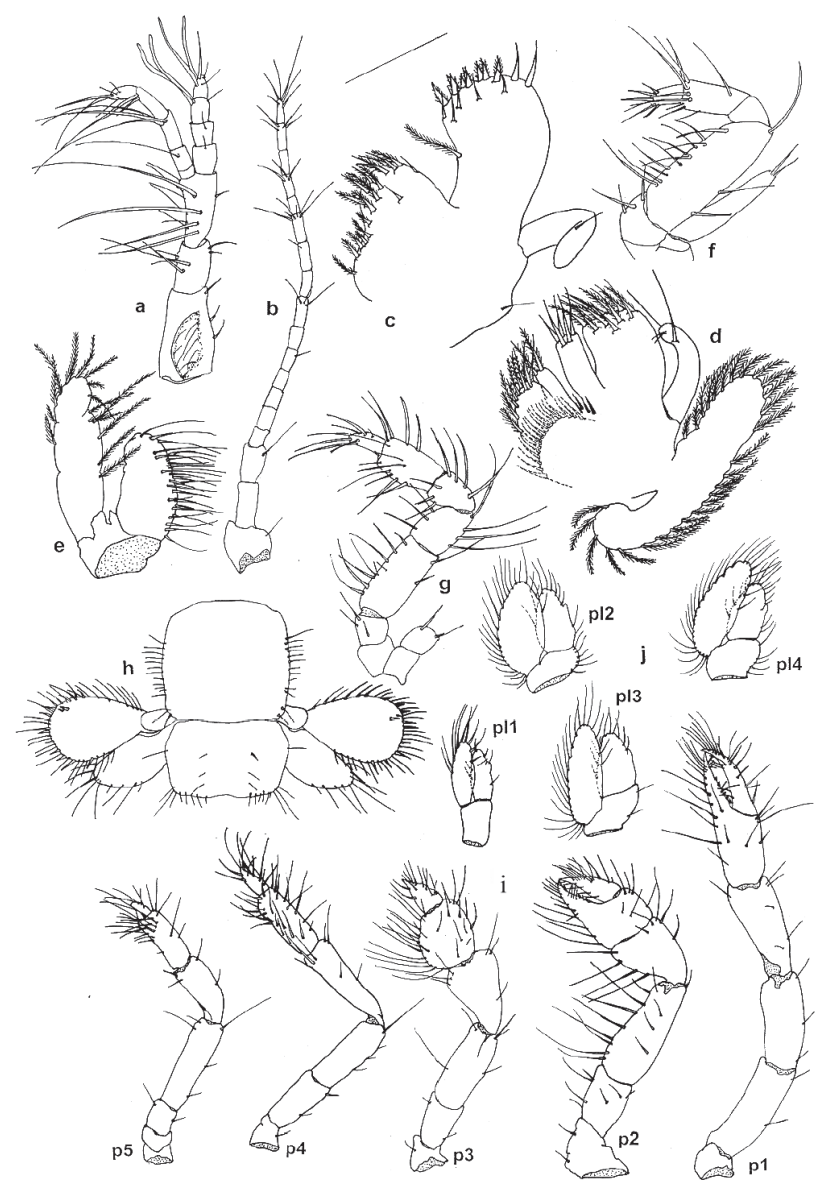

Figure 9 - Lepidophtalmus siriboia Felder \& Rodrigues, 1993. Juvenile appendages. a, Antennule; b, Antenna; c, Maxillule; d, Maxilla; e, First maxilliped; f, Second maxilliped; g, Third maxilliped; h, Telson; i, Pereiopods (p1- p5); j, Pleopods (pl 1 - pl 4). Scale bar: a, b, g, h, j and I $=0.3 \mathrm{~mm} ; \mathrm{c}=0.07 \mathrm{~mm}$;, $\mathrm{d}$, $\mathrm{e}, \mathrm{f}=0.1 \mathrm{~mm}$. 


\section{ACTA \\ AMAZONICA}

Third maxilliped (Fig. 9g) - Exopod 2-segmented, with 2 simple terminal setae; endopod 6-segmented, with $3,11,7,7,12,7$ setae, respectively.

Pereiopods 1 e 2 (Figs. 9i) - Uniramous; chelated; endopod 6-segmented, propodus and dactylus with numerous setae; exopod atrophied. Pereiopod 1 with ischium, merus and dactylus with few setae; fixed finger with 5 spines in the inner margin. Pereiopod 2 smaller compared with pereiopod 1 , fixed finger with 4 spines in the inner margin.

Pereiopods 3e 4(Figs. 9i)-Uniramous; endopod 6-segmented; propodus and dactylus with numerous setae; exopod atrophied. Pereiopod 3 showing all segmentations smaller when compared with pereiopod 4 .

Pereiopod 5 (Fig. 9i) - Uniramous; endopod 6-segmented; propodus and dactylus with numerous setae; exopod atrophied.

Pleopod 1 (Fig. 9j)-Biramous; basipod lacking setae; endopod with 7 plumose setae; exopod with 10 plumose setae.

Pleopod 2-4 (Fig. 9j) - Biramous; basipods with 2-6 setae; endopods with 10-13 plumose setae; exopods with 2024 plumose setae.

Telson (Fig. 9h) - Telson subrectangular with 21 marginal setae;

Uropod (Fig. 9h) - Uropod biramous; exopod larger than endopod; exopod with 28 plumose setae and 11 marginal spines; endopod with 9 plumose marginal setae.

\section{DISCUSSION}

The results of the present study showed relevant differences between congeneric species previously reported in other literature. Nates $e t$ al. (1997) described an abbreviated development for L. louisianensis and L. sinuensis. These species go through only two zoeal stages before metamorphosis into megalopa. However, an additional zoeal stage was observed for L. siriboia .

These species show similar results in the stage I period. The duration of the two initial stages for L. siriboia averaged 43 hours, which was longer than L. sinuensis (31.8 hours) but shorter than L. louisianensis (50-55 hours). The additional stage of $L$. siriboia extends the complete larval period form metamorphosis to megalopa (69 hours), whereas this same period was only 30 and 40 hours for $L$. sinuensis and L. louisianensis, respectively. Thus, based on the present study the number of stages may not be considered a characteristic of the genus Lepidophtbalmus as was suggested by Nates et al. 1997.

Table 1 - Morphological differences between the Zoea I of Lepidophthalmus sinuensis e L. louisianensis (described by Nates et al., 1997) and L. siriboia (present study). Abbreviations: a, absent; s, setation; e, aesthetascs; esp., spine.

\begin{tabular}{|c|c|c|c|c|}
\hline & & L.sinuensis & L. louisianensis & L.siriboia \\
\hline \multicolumn{5}{|l|}{ Antennule } \\
\hline Endopod & $\mathrm{s}$ & 1 & 1 & 1 \\
\hline Exopod & $\mathrm{s}+\mathrm{e}$ & $(2+2)+6$ & $5+1$ & $2+5$ \\
\hline \multicolumn{5}{|l|}{ Antenna } \\
\hline Flagellum & $a$ & $a$ & $\mathrm{a}$ & \\
\hline Endopod & $\mathrm{s}$ & 2 & 0 & 3 \\
\hline Exopod & $\mathrm{s}$ & $(8-9)+1$ & $(8-9)+1$ & $(11-12)+1$ \\
\hline Protopod & $\mathrm{s}$ & 1 & 1 & 1 \\
\hline \multicolumn{5}{|l|}{ Maxillule } \\
\hline Coxal endite & $\mathrm{s}$ & 0 & 0 & $0-3$ \\
\hline Basal endite & esp. & 0 & 2 & $2-4$ \\
\hline Endopod & $\mathrm{s}$ & $0+0$ & $0+0$ & 0 \\
\hline \multicolumn{5}{|l|}{ Maxilla } \\
\hline Coxal endite & $\mathrm{s}$ & $0+0$ & $0+0$ & $0+0$ \\
\hline Basal endite & $\mathrm{s}$ & $0+0$ & $1+2$ & $0+0$ \\
\hline Endopod & $s$ & $0+0$ & $1+2$ & $0+0$ \\
\hline Scaphognathite & $\mathrm{s}$ & $(3+1)+2$ & 3 & $(3-4)+2$ \\
\hline \multicolumn{5}{|l|}{ First maxilliped } \\
\hline Coxa & $s$ & 0 & 0 & 0 \\
\hline Basipod & $\mathrm{s}$ & 0 & 3 & 0 \\
\hline Endopod & $\mathrm{s}$ & 0 & $1,0,2$ & $(2-3)$ \\
\hline Exopod & $\mathrm{s}$ & $2+2$ & $2+2$ & $2+2$ \\
\hline Epipodite & $\mathrm{s}$ & $\mathrm{P}$ & $\mathrm{a}$ & $\mathrm{a}$ \\
\hline \multicolumn{5}{|c|}{ Second maxilliped } \\
\hline Coxa & $\mathrm{s}$ & 0 & 0 & 0 \\
\hline Basipod & $\mathrm{s}$ & 0 & 0 & 0 \\
\hline Endopod & $s$ & $0,0,0,2$ & $0,0,0,2$ & $1+1$ \\
\hline Exopod & $\mathrm{s}$ & $0,2+3$ & $0,0,2+2$ & $2+2$ \\
\hline \multicolumn{5}{|c|}{ Third maxilliped } \\
\hline Coxa & $\mathrm{s}$ & 0 & 0 & 0 \\
\hline Basipod & $\mathrm{s}$ & 0 & 0 & 0 \\
\hline Endopod & $\mathrm{s}$ & 2 & $0,0,0,2$ & $2+1$ \\
\hline Exopod & $\mathrm{s}$ & $0,2+3$ & $0,2,+3$ & $2+3$ \\
\hline \multicolumn{5}{|l|}{ Telson } \\
\hline Process & $\mathrm{s}$ & $14+1+14$ & $10+1+10$ & $7+1+7$ \\
\hline Uropod & & a & a & $\mathrm{a}$ \\
\hline Endopod & & a & a & $\mathrm{a}$ \\
\hline Exopod & & $\mathrm{a}$ & $\mathrm{a}$ & $\mathrm{a}$ \\
\hline
\end{tabular}




\section{ACTA AMAZONICA}

LARVAL DEVELOPMENT OF LEPIDOPHTHALMUS SIRIBOIA FELDER \& RODRIGUES, 1993 (DECAPODA: THALASSINIDEA) FROM THE AMAZON REGION, REARED IN THE LABORATORY.
In terms of and larval morphology, several differences were observed between L. siriboia, L. louisianensis L. sinuensis (Table $1)$. The number of setae in the telson for $L$. louisianensis $(10+1+10)$ and for $L$. sinuensis $(14+1+14)$ and a reduced number of setae for $S$. siriboia $(7+1+7)$ appear to be very characteristic for evident distinction between these species.

There is similar Morphology in the feeding appendages of L. siriboia and the congeneric species during all zoeal development. The three species show the inner portion of the maxillae, and absence or reduced number of spines and setae in the endopods of the first and second maxillipeds (Figure 4, 5 and 6) (Table 1). These larval characteristics might be associated to feeding habits. Complete or facultative developments were reported for L. louisianensis (Nates \& McKenneyJr, 2000). Other members of the Callianassidae family have presented similar feeding behavior such as Callianassa tyrrbena (Thessalou-Legaki et al., 1999). In addition, these species also have abbreviated larval development. According to Thessalou-Legaki et al. (1999) the complete or facultative development can be regarded as an adaptation of a species to the environmental conditions. Contrarily, Melo \& Brossi-Garcia (2000) reported that thalassinid Upogebia paraffinis, which belongs to the same infraordem of $L$. siriboia, has feeding appendages very setose and functional. This fact indicates that a large variation of larval development can be found among the thalassinids species.

There are some studies reporting a variable number of stages among the callianassids species. Thessalou-Legaki et al. (1999) and Rodrigues (1984) described Callianassa tyrrbena and Callichirus mirim (= Sergio mirim) as having only two larval stages. Strasser \& Felder (1999) reported that Callichirus islagrande goes through five stages before metamorphosis.

Significant changes occur after molting into megalopa stage. The former structures become heavily setose and evidently functional. This fact suggests that $L$. siriboia has lecithotrophic larval development and feeding behavior occurs for the first time in the megalopa stage. Further studies are needed to understand their feeding characteristics.

\section{LITERATURE CITED}

Felder, D. L.; Rodrigues, S. de A. 1993. Reexamination of the ghost shrimp Lepidophtalmus louisianensis (Schmitt, 1935) from the Northern Gulf of Mexico and comparison to L. siriboia, a new species, from Brazil (Decapoda: Thalassinidea: Callianassidae). Journal of Crustacean Biology, 13 (2): 357-376.
Melo, G. A. S. 1999. Manual de identificação dos Crustacea Decapoda do litoral brasileiro: Anomura, Thalassinidea, Palinuridea Astacidea . Edit. Plêiade/Fadesp, São Paulo. 370-371.

Melo, S. G.; Brossi-Garcia, A. L. 2000. Postembryonic development of Upogebia paraffinis Williams, 1993 (Decapoda, Thalassinidea), reared under laboratory conditions. Nauplius, 8 (1): 149-168.

Nates, S. F.; Felder, L. D.; Lemaitre, R. 1997. Comparative larval development in two species of the burrowing ghost shrimp genus Lepidophthalmus (Decapoda: Callianassidae). Journal of Crustacean Biology, 17 (3): 497-519.

Nates, S. F.; Mckenneyjr, C. L. 2000. Ontogenic changes in biochemical composition during larval and early postlarval development of Lepidophthalmus louisianensis, a ghost shrimp with abbreviated development. Comparative Biochemistry and Physiology, part b. Biochemistry and Molecular Biology, 127 (4): 459-468.

Rodrigues, S. de A.; Shimizu, R. M. 1998. Malacostraca-Eucarida. Thalassinidea. In: Young, P.S. (ed.) Catalogue of Crustacea of Brazil. Rio de Janeiro: Museu Nacional. pp. 279-385.

Rodrigues, S. de A. 1976. Sobre a reprodução, embriologia e desenvolvimento larval de Callichirus major Say, 1818 (Crustacea, Decapoda, Thalassinidea). Boletim de Zoologia da Universidade de São Paulo, 1: 85-104.

Rodrigues, S. de A. 1984. Desenvolvimento pós-embrionário de Callichirus mirim (Rodrigues, 1971) obtido em condições artificiais (Crustacea, Decapoda Thalassinidea). Boletim Zoologia da Universidade de São Paulo, 8: 239-256.

Strasser, K. M.; Felder, D. L. 1999. Larval development of two populations of the ghost shrimp Callichirus major (Decapoda: Thalassinidae) under laboratory conditions. Journal of Crustacean Biology, 19: 844-878.

Thessalou-Legaki, M. Peppa, A.; Zacharaki. 1999. Facultative lecithotrophy during larval development of the burrowing shrimp Callianassa tyrrbena (Decapoda: Callianassidae). Marine Biology, 133: 635-642.

\section{RECEBIDO EM 25/08/2004 ACEITO EM 21/01/2005}

